Brazilian Journal

of Chemical

ISSN 0104-6632

Engineering

\title{
ISOLATION AND CHARACTERIZATION OF A HIGH SALT-TOLERANT AND GLYPHOSATE-DEGRADING STRAIN OF Agrobacterium tumefaciens BZ8
}

\author{
Shoubao Yan ${ }^{1,2}$, Wei Zhao ${ }^{1}$, Cuie Shi ${ }^{1 *}$, Qianqian Tong ${ }^{1}$, Zhijun Zhai ${ }^{3}$ and Yun Wang ${ }^{1 *}$ \\ ${ }^{1}$ School of Life Science, Huainan Normal University, Huainan, Anhui Province, 232001, People's Republic of China \\ *E-mails: shicuie1025@163.com; 1176144756@qq.com; Phone: +86 5546641722; Fax: +86 5546863540. \\ ${ }^{2}$ Liquor Making Biological Technology and Application of Key Laboratory of Sichuan Province, Zigong, \\ Sichuan Province, 643000, People's Republic of China \\ ${ }^{3}$ School of Life Science, Jiangxi Agricultural University, Jiangxi Province, 230026, People's Republic of China
}

(Submitted: December 15, 2015; Revised: April 16, 2016; Accepted: April 16, 2016)

\begin{abstract}
In this study, a high salt-tolerant and glyphosate-degrading strain named BZ8 was isolated from activated sludge. According to $16 \mathrm{~S}$ rDNA sequencing methods, morphological, physiological and biochemical analysis, strain BZ8 was identified as Agrobacterium tumefaciens. The growth and glyphosate-degrading capability of $A$. tumefaciens BZ8 were investigated and the results showed that the optimum conditions for glyphosate degradation under $6 \%$ of $\mathrm{NaCl}$ concentration were found as follows: inoculation size of $10 \%(\mathrm{v} / \mathrm{v})$, incubation temperature $37^{\circ} \mathrm{C}$ and initial $\mathrm{pH}$ of 5.0. Salt tolerance test showed that $A$. tumefaciens BZ8 grew well and could thoroughly degrade $2000 \mathrm{mg} / \mathrm{L}$ glyphosate in $36 \mathrm{~h}$ if the concentration of $\mathrm{NaCl}$ was lower than $6 \%$, while the degradation rate decreased gradually with increasing $\mathrm{NaCl}$ concentration. But the glyphosate degradation rate could still reach $62 \%$ when the salt concentration was $8 \%$. In addition, the kinetic parameters for A. tumefaciens BZ8 grown on 100-2800 mg/L glyphosate according to Haldane's model could predict the cell growth tendency successfully. These results showed that $A$. tumefaciens BZ8 could be used to control glyphosate wastewater with high salt content. Therefore, it has potential application.
\end{abstract}

Keywords: salt-tolerant; glyphosate-degrading strain; identification; growth kinetics.

\section{INTRODUCTION}

Glyphosate is the most widely used herbicide in the world because it is a cheap, high efficient, low residue, broad-spectrum and foliar applied weed-killer. It can be used on non-cropland as well as on a great variety of crops. Nowadays, China is the largest exporter of glyphosate in the world. However, during the production of glyphosate, the discharge of wastewater can cause serious water pollution problems and environmental damage (Xu et al.,
2007). This is because the wastewater mainly contains glyphosate, $\mathrm{NaCl}$ and so on (Amoros et al., 2007). It was reported that producing one ton of glyphosate could cause production of 5-6 tons of glyphosate wastewater. Therefore, it is necessary to find safe and effective treatment methods for glyphosate wastewater.

Up to now, several technologies, which can be defined as physical methods, chemical techniques and biological treatments, have been developed for the treatment of glyphosate wastewater. Among these, physical and

\footnotetext{
* To whom correspondence should be addressed
} 
chemical methods have proven to be costly and always produce additional harmful pollution. Biological treatment is more economical than physical and chemical methods because it can be cost-effective and achieve the complete degradation of organic pollutants (Fan et al., 2012). Therefore, biological treatment of glyphosate wastewater has received increased attention for contamination prevention, and a number of different microorganisms, including yeast (Tang and Chen, 2010), Pseudomonas (Wu et al., 2010), Flavobacterium (Terry et al., 1986), Arthrobacter (Pipke and Amrhein, 1988) etc., have been isolated and tested for their ability to degrade glyphosate. However, there have been few studies on microorganisms that can function under the conditions of high $\mathrm{NaCl}$ concentration.

In this study, a salt-tolerant and glyphosatebiodegrading bacterium was screened from activated sludge and identified. In addition, the effects of environmental factors such as inoculation size, initial $\mathrm{pH}$, temperature and salinity on the growth and glyphosate biodegradation were evaluated. The intrinsic kinetics of the growth on glyphosate using the Haldane model was also investigated. The aim of this study was to provide possible new resources for glyphosate wastewater treatment.

\section{MATERIALS AND METHODS}

\section{Isolation of the salt-resistant and glyphosate- degrading strain}

Activated sludge samples collected from a glyphosate wastewater treatment plant located in Anhui Hong Sifang Co., Ltd. currently manufacturing glyphosate in Hefei, Anhui province, People's Republic of China were acclimated for one mouth in the selection medium (SM) supplemented with $500-2000 \mathrm{mg} / \mathrm{L}$ glyphosate and 60 $\mathrm{g} / \mathrm{L} \mathrm{NaCl}$ for selection of a salt-tolerant and glyphosatedegrading strain. The $\mathrm{SM}$ contained $(\mathrm{g} / \mathrm{L}) \mathrm{KH} 2 \mathrm{PO} 4$ (0.5), K2HPO4 (0.5), MgSO4·7H2O (0.5), CaCl2 (0.04). Initially, $10 \mathrm{~g}$ of the samples were inoculated into $90 \mathrm{~mL} \mathrm{SM}$ with $500 \mathrm{mg} / \mathrm{L}$ glyphosate and incubated at $37^{\circ} \mathrm{C}, 200 \mathrm{rpm}$ for one week. Then, $10 \%$ of the culture was sub-cultured in SM with a glyphosate concentration of $1000 \mathrm{mg} / \mathrm{L}$ under the conditions as described above. The process was repeated until $2000 \mathrm{mg} / \mathrm{L}$ glyphosate was biodegraded by the samples. Then the resulting culture was serially diluted with sterilized water and spread onto selection medium agar plates supplemented with $2000 \mathrm{mg} / \mathrm{L}$ glyphosate as the sole carbon source. The plates were incubated at $37^{\circ} \mathrm{C}$. Colonies that appeared on the plates were picked out and streaked several times to obtain pure isolates.

The obtained strains were stored on slants at $4{ }^{\circ} \mathrm{C}$ and their glyphosate-degrading potential tested by inoculating the pure cultures into replicated flasks. Each flask contained $100 \mathrm{~mL}$ SM supplemented with $2000 \mathrm{mg} / \mathrm{L}$ glyphosate. The cultures were maintained at $37^{\circ} \mathrm{C}$ with a shaker speed of 200 $\mathrm{rpm}$. The strain that completely metabolized glyphosate at the fastest rate was chosen for further research.

Identification of the salt-resistant and glyphosatedegrading strain

The screened strain was characterized and identified based on its morphological, biochemical properties and 16S rRNA gene sequence analysis. The obtained cells of exponential growth phase in SM were harvested by centrifugation at $12000 \mathrm{rpm}, 4^{\circ} \mathrm{C}$ for $20 \mathrm{~min}$ and washed with sterile water. By using the method mentioned by Zhai et al. (Zhai et al., 2012), the genome of the strain was extracted.

Part of the 16S rRNA gene was amplified by PCR using the forward primer: Eu27F (5'-AGAGTTTGATCATGGCTCAG-3') and the reverse primer: 1492R (5'-TACGGCTACCTTGTTACGACTT-3'). DNA amplifications were performed in $50 \mu \mathrm{L}$ reactions containing approximately $100 \mathrm{ng}$ of total DNA, $4 \mu \mathrm{L}$ of $10 \times$ buffer, $4 \mu \mathrm{L}$ of $25 \mathrm{mmol} / \mathrm{L} \mathrm{MgCl} 2,4 \mu \mathrm{L}$ of $2.5 \mathrm{mmol} / \mathrm{L}$ dNTPs, $2 \mu \mathrm{L}$ of each $10 \mathrm{mmol} / \mathrm{L}$ primer and $0.4 \mu \mathrm{L}$ of $5 \mathrm{U} /$ $\mu \mathrm{L}$ Taq polymerase. The PCR conditions were as follows: $94^{\circ} \mathrm{C}$ for $3 \mathrm{~min}$ followed by 30 cycles of denaturation at $94^{\circ} \mathrm{C}$ for $30 \mathrm{~s}$, annealing at $55^{\circ} \mathrm{C}$ for $30 \mathrm{~s}$ and primer extension at $72^{\circ} \mathrm{C}$ for $2 \mathrm{~min}$, followed by a final step at $72^{\circ} \mathrm{C}$ for $10 \mathrm{~min}$. PCR products were purified using a commercial kit (Sangon, Shanghai, China), and then the obtained purified PCR products were sequenced by Sangon Biotech Company (Shanghai, China). The sequencing result was submitted to GenBank for BLAST analysis. A phylogenetic tree was constructed by the neighbor-joining method using the software MEGA 4.0 (Tamura et al., 2007).

Colony morphology was observed after cultivation on $\mathrm{SM}$ at $37^{\circ} \mathrm{C}$ for $24 \mathrm{~h}$. Cell morphology was examined after $24 \mathrm{~h}$ of incubation at $37^{\circ} \mathrm{C}$ by optical microscopy (CX31, OLYMPUS, Japan). Gram staining was performed by a conventional method (Dong and Cai 2001). After heat treatment at $80^{\circ} \mathrm{C}$ for $10 \mathrm{~min}$, the presence of spores was investigated by optical microscopy following crystal violet staining for $2 \mathrm{~min}$. Activities of catalase and nitrate reductase, hydrolysis of starch and glutin, utilization of citrate, nitrate reduction and production of indole were carried out according to the conventional methods (Smibert et al., 1994; Dong and Cai, 2001). The utilization of various substrates (sucrose, maltose, glycerol, D-galactose, xylose, D-glucitol, mannitol) as the sole carbon source was conducted according to the methods reported by Liu et al. (2014).

\section{Biodegradation experiments}

The stored culture of strain BZ8 maintained on a nutrient agar slant was inoculated into $100 \mathrm{~mL}$ SM supplemented with $2000 \mathrm{mg} / \mathrm{L}$ glyphosate. Then the bacterial sub-culture 
at the late exponential phase was used as inoculum. The biodegradation experiments were performed in $500 \mathrm{~mL}$ flasks with a working volume of $100 \mathrm{~mL}$ at $200 \mathrm{rpm}$.

In order to investigate the influence of initial inoculation size, initial $\mathrm{pH}$ and temperature on glyphosate degradation, replicate flasks with SM supplemented with $2000 \mathrm{mg} / \mathrm{L}$ glyphosate and $60 \mathrm{~g} / \mathrm{L} \mathrm{NaCl}$ were conducted at initial inoculum sizes varying from $2 \%$ to $15 \%$, initial $\mathrm{pH}$ ranges from 3 to 7 and temperatures from $20^{\circ} \mathrm{C}$ to $42^{\circ} \mathrm{C}$, respectively. A similar experimental procedure was used for testing the capacity of the strain BZ8 to degrade glyphosate under the optimized conditions.

The effect of $\mathrm{NaCl}$ concentrations on glyphosate degradation was investigated by applying different $\mathrm{NaCl}$ concentration $(20,40,60,80$ and $100 \mathrm{~g} / \mathrm{L})$ at a constant glyphosate concentration of $2000 \mathrm{mg} / \mathrm{L}$.

For the estimation of intrinsic kinetic parameters, a pure culture of strain BZ8 was inoculated into $100 \mathrm{~mL} \mathrm{SM}$ in $500 \mathrm{~mL}$ flasks with $60 \mathrm{~g} / \mathrm{L} \mathrm{NaCl}$ under the optimized conditions. The SM was supplemented with glyphosate concentrations varying from 100 to $2800 \mathrm{mg} / \mathrm{L}$. All the experiments were performed in triplicate. Culture samples were regularly taken for measurement of biomass and glyphosate concentration, and results were shown as means \pm confidence intervals.

\section{Glyphosate degradation kinetics}

The most commonly used kinetic model to describe microbial growth is the Monod kinetic model. However, this model does not represent the growth kinetics of inhibitory substrates. Haldane's model developed from the Monod kinetic model has been used widely to characterize the metabolic inhibition of substrate on the microbial growth (Li et al., 2010). Therefore, in this study, Haldane's equation was used to describe strain BZ8 growth kinetics. For each flask with a certain initial glyphosate concentration, the specific growth rate $(\mu \mathrm{x}, 1 / \mathrm{h})$ was calculated as:

$$
\mu_{x}=\frac{\mathrm{r}_{x}}{\rho_{x}}=\frac{d \rho_{x}}{d t} \frac{1}{\rho_{x}}
$$

where $r x$ is the cell growth rate $(\mathrm{mg} / \mathrm{L} / \mathrm{h})$ and $\rho x$ is the cell concentration $(\mathrm{mg} / \mathrm{L})$. Then $\mu \mathrm{x}$ was modeled using Haldane's model described as follows:

$$
\mu_{x}=\frac{\mu_{\max } \rho_{\mathrm{S}}}{K_{s}+\rho_{\mathrm{S}}+\rho_{\mathrm{S}}^{2} / K_{\mathrm{SI}}}
$$

where $\mu$ max is the maximum specific cell growth rate $(1 / \mathrm{h}), \rho \mathrm{S}$ is the glyphosate concentration $(\mathrm{mg} / \mathrm{L}), \mathrm{KS}$ is the saturation constant $(\mathrm{mg} / \mathrm{L})$, and $\mathrm{KSI}$ is the self-inhibition constant $(\mathrm{mg} / \mathrm{L})$.
The yield coefficient (mg dry cell mass/mg glyphosate) Ym was calculated using the following equation:

$$
Y_{m}=\frac{M_{\max }-M_{i}}{\rho_{S_{i}}-\rho_{S_{r}}}
$$

where Mmax is the maximum biomass concentration $(\mathrm{mg} / \mathrm{L}), \mathrm{Mi}$ is the initial cell concentration $(\mathrm{mg} / \mathrm{L}), \rho \mathrm{Si}$ is the initial substrate concentration $(\mathrm{mg} / \mathrm{L})$, and $\rho \mathrm{Sr}$ is the residual glyphosate concentration when the cell concentration reached the maximum $(\mathrm{mg} / \mathrm{L})$.

\section{Analytical procedures}

The cell concentration was monitored spectrophotometrically at $600 \mathrm{~nm}$. The uninoculated sterile medium was used as a control. The optical density (OD) value was then converted to dry cell mass (DCW) using a calibration curve (Vasiliadou et al., 2008). The relationship between DCW and OD was found to be DCW $(\mathrm{mg} / \mathrm{L})=287.3 \times \mathrm{OD}_{600}-3.27 ; \mathrm{R}^{2}=0.9997$. The concentration of glyphosate in the culture was determined by a high performance liquid chromatography (HPLC) method on a 1100 series HPLC (Agilent, American) as described by Kawai et al. (1991).

\section{RESULTS AND DISCUSSION}

\section{Characterization and identification of glyphosate- degrading strain BZ8}

Several strains were isolated from activated sludge by the method mentioned above. The glyphosate degradation ability was confirmed by the glyphosate degradation rate. Among them, a bacterium, named BZ8, was found to exhibit the highest glyphosate degradation ability and thus was chosen for further study. Colonies of strain BZ8 were smooth, round, moderate humidity, neat edges and white opaque. This bacterium is non-spore-forming, aerobic and gram-negative rod-shaped. It was V.P experiment-negative, nitrate reductase-positive, catalase-negative, utilization of citrate, hydrolysis of starch, glutin-positive and indole production-negative. It also utilizes sucrose, maltose, glycerol, D-galactose, xylose, D-glucitol, mannitol as sole carbon sources for growth.

The 16S rRNA gene is a highly conserved gene and was used for the phylogenetic analysis of taxa at higher levels. The 16S rRNA gene sequences of strain BZ8 were obtained (comprising 1385 nucleotides) and submitted to GenBank (http://www.ncbi.nlm.nih.gov). The sequence displayed the highest similarity (99\%) to that of A. tumefaciens (GenBank accession AB535688.1 and FR828338.1). A phylogenetic tree was constructed based on the $16 \mathrm{~S}$ 
rRNA coding gene sequences of the isolate and the nearest relatives (Fig. 1). Combined with the morphological, physiological and biochemical analysis, the strain can be identified as $A$. tumefaciens. So, this strain was named $A$. tumefaciens BZ8.

Effects of inoculation size, initial $\mathrm{pH}$, temperature and salinity on glyphosate degradation

Fig. 2 illustrates the effect of inoculation size on the glyphosate degradation of A. tumefaciens BZ8. Experiments were carried out with the same initial glyphosate concentration of $2000 \mathrm{mg} / \mathrm{L}$. It was obvious that the glyphosate concentration decreased with time for different inoculation sizes. Glyphosate was thoroughly degraded after $54 \mathrm{~h}, 48 \mathrm{~h}, 34 \mathrm{~h}$ and $36 \mathrm{~h}$ at inoculation sizes of $2 \%, 5 \%, 10 \%$ or $15 \%$, respectively (Fig. 2). The effect of inoculum size on cell growth of strain BZ8 is also shown in Fig. 2. As shown in Fig. 2, with the increase of inoculum size, the lag period of the cell growth shortened gradually, while the cell growth rate and the substrate utilization rate were accelerated. Table 1 presents the values of glyphosate degradation rate with respect to inoculation size. The glyphosate degradation rate was greatly increased with inoculation size up to $10 \%(\mathrm{v} / \mathrm{v})$, but it kept almost constant as the inoculation size further increased up to $15 \%$. Taking into account the growth of strain BZ8 and glyphosate degradation, $10 \%(\mathrm{v} / \mathrm{v})$ was chosen as the optimum inoculum size and used for all following experiments.

Glyphosate degradation and the cell growth were also tested at various initial pH values (Fig. 3). As expected, the $\mathrm{pH}$ greatly influenced glyphosate degradation as well as cell growth in the strain BZ8 culture system. Fig. 3 illustrates that the growth of strain BZ8 was positively related with the glyphosate degradation. The optimal $\mathrm{pH}$ for $A$. tumefaciens BZ8 growth occurred at $\mathrm{pH}$ 5.0. The shortest time to degrade glyphosate thoroughly occurred at pH 5.0. Apparently, a $\mathrm{pH}$ value of 5.0 would be the optimum for degradation of glyphosate by this bacterial strain. However, there was no distinct difference in glyphosate degradation rate as $\mathrm{pH}$ increased from 4.0 to 6.0 (Table 1). Although the glyphosate biodegradation efficiencies of the other two systems (pH 3.0 and pH 7.0) were significantly delayed, the strain BZ8 was still capable of entirely consuming glyphosate. This special $\mathrm{pH}$ adaptability indicates that the strain BZ8 could be applied to acidic or neutral conditions without altering the $\mathrm{pH}$.

The influence of temperature on the glyphosate degradation and growth of strain BZ8 is illustrated in Fig. 4. The results show that strain BZ8 could effectively degrade glyphosate in the temperature range from $30^{\circ} \mathrm{C}$ to $42^{\circ} \mathrm{C}$. Especially under the temperature of $37^{\circ} \mathrm{C}$, BZ8 showed higher efficiency of glyphosate degradation as compared to the other three temperatures. The glyphosate degradation rate was seen to decrease with increasing or falling temperature (Table 1). However, at a low temperature of $20^{\circ} \mathrm{C}$ and a high temperature of $42^{\circ} \mathrm{C}$ the strain BZ8 could still degrade glyphosate thoroughly within $70 \mathrm{~h}$ and $40 \mathrm{~h}$, respectively. Therefore, strain BZ8 is a potentially useful microorganism that could function at both comparatively low and high temperatures. This broad temperature adaptability may be important for biodegradation in glyphosate-contaminated environments that undergo daily and seasonal temperature changes.

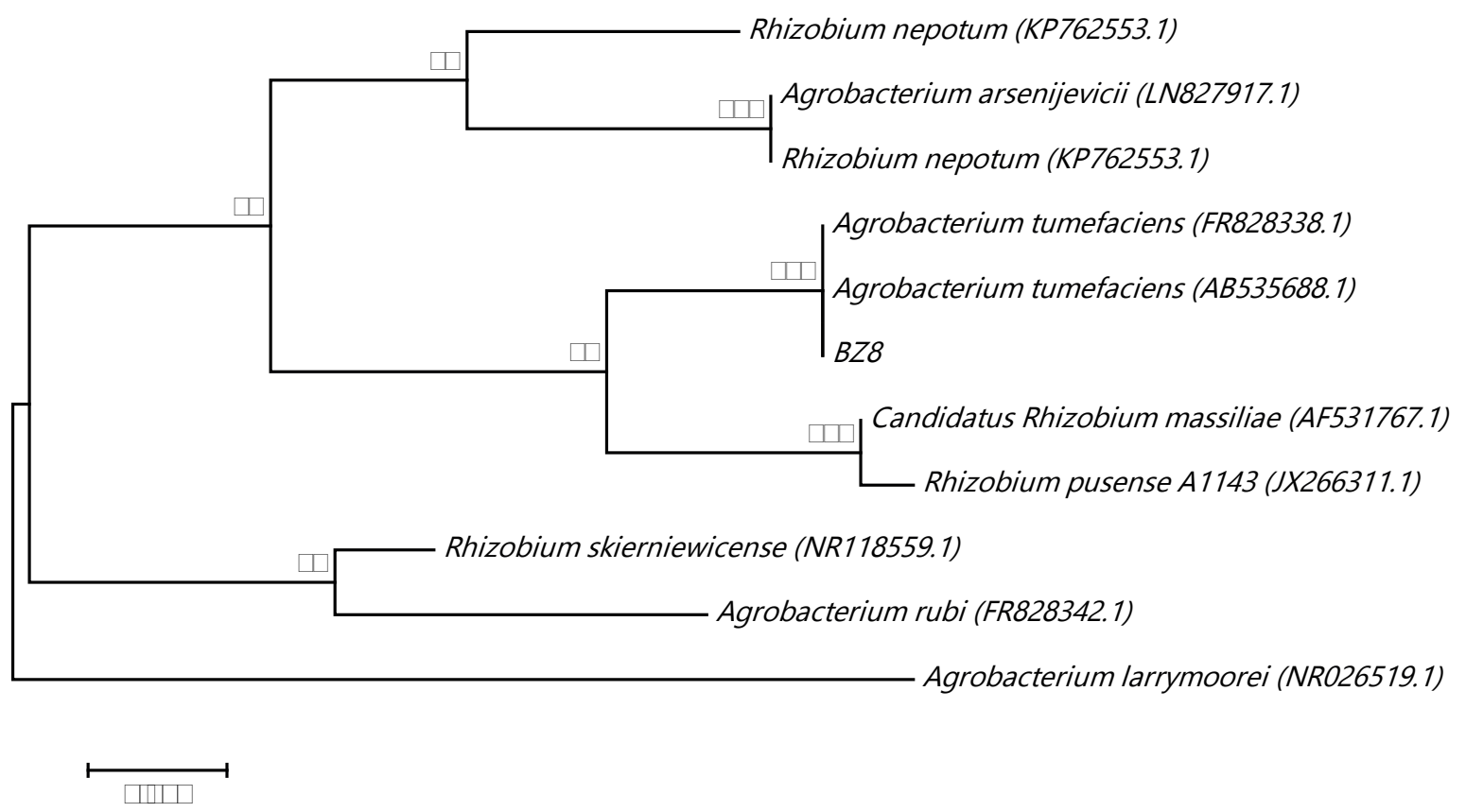

Figure 1. Phylogenetic tree of strain BZ8 based on 16S rRNA gene sequence analysis. Bootstrap values obtained with 1000 repetitions are indicated as percentages at all branches. The scale bar indicates 0.002 substitutions per nucleotide position. 


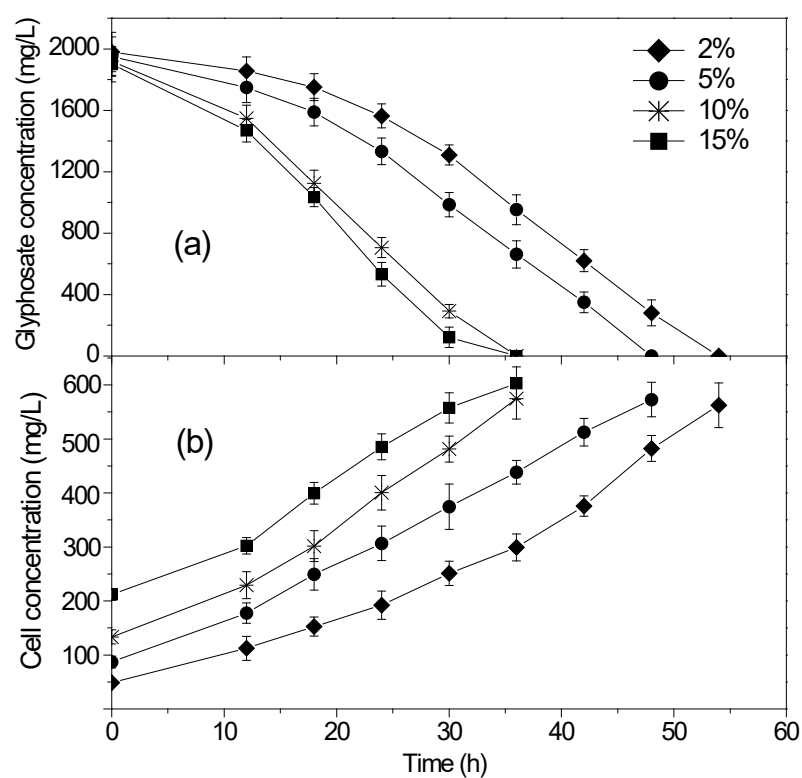

Figure 2. Effect of inoculum size on biodegradation of glyphosate (a) and cell growth (b) by strain BZ8

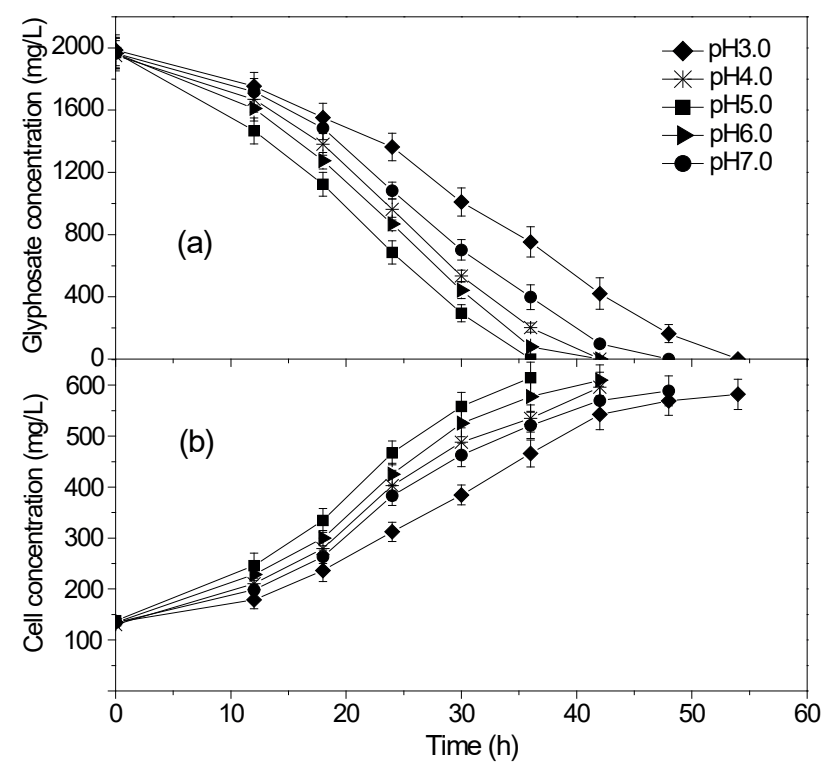

Figure 3. Effect of $\mathrm{pH}$ on biodegradation of glyphosate (a) and cell growth (b) by strain BZ8

Table 1. Glyphosate degradation rates of A. tumefaciens BZ8 under different conditions

\begin{tabular}{cccccc}
\hline $\begin{array}{c}\text { Initial inoculum } \\
\text { size } \\
(\%)\end{array}$ & $\begin{array}{c}\text { Glyphosate degradation } \\
\text { rate } \\
(\mathrm{mg} / \mathrm{L} / \mathrm{h})\end{array}$ & $\begin{array}{c}\text { Initial } \\
\mathrm{pH}\end{array}$ & $\begin{array}{c}\text { Glyphosate degradation } \\
\text { rate } \\
(\mathrm{mg} / \mathrm{L} / \mathrm{h})\end{array}$ & $\begin{array}{c}\text { Culture } \\
\text { temperature } \\
\left({ }^{\circ} \mathrm{C}\right)\end{array}$ & $\begin{array}{c}\text { Glyphosate } \\
\text { degradation rate } \\
(\mathrm{mg} / \mathrm{L} / \mathrm{h})\end{array}$ \\
\hline 2 & 36.67 & 3 & 36.76 & 20 & 26.5 \\
5 & 40.63 & 4 & 46.43 & 30 & 47.12 \\
10 & 54.16 & 5 & 54.78 & 37 & 55.18 \\
15 & 53.33 & 6 & 46.79 & 42 & 46.15 \\
- & - & 7 & 40.93 & - & - \\
\hline
\end{tabular}

A. tumefaciens BZ8 grew well over the temperature ranges from $30^{\circ} \mathrm{C}$ to $42^{\circ} \mathrm{C}$, which was significantly different at $20^{\circ} \mathrm{C}$ (Fig. 4). It reached the stable phase after $36 \mathrm{~h}$ at $30-42^{\circ} \mathrm{C}$. At $20^{\circ} \mathrm{C}$, the stable phase was recorded after 66 h. The fastest cell growth speed of BZ8 occurred at $37^{\circ} \mathrm{C}$. According to these results, the temperature of $37^{\circ} \mathrm{C}$ was applied in the following set of experiments.

The actual glyphosate wastewater normally contains various concentrations of $\mathrm{NaCl}$, which directly influences the activity of glyphosate-degrading microorganisms. In this study, strain BZ8 was inoculated into SM medium with $2000 \mathrm{mg} / \mathrm{L}$ glyphosate at different $\mathrm{NaCl}$ concentrations and incubated at $37^{\circ} \mathrm{C}$ for $36 \mathrm{~h}$. As shown in Fig. 5, the strain grew well and glyphosate could be completely degraded in $36 \mathrm{~h}$ when the concentration of $\mathrm{NaCl}$ was lower than $60 \mathrm{~g} / \mathrm{L}$. With increasing salt concentration, the cell growth was inhibited gradually and the glyphosate degradation rate decreased greatly. The possible reason is that high salinity could cause osmotic stress or inhibit the reaction pathways in the organic degradation process. This results in a significant decrease in biological treatment efficiency or biodegradation kinetics. In addition, high salt content induces cell lysis, which causes increased effluent solids. However, the glyphosate degrading rate of strain BZ8 could still achieve $62 \%$ when the salt concentration reached $80 \mathrm{~g} / \mathrm{L}$. Compared with the other salinities, strain BZ8 grew difficultly at the salinity of $100 \mathrm{~g} / \mathrm{L}$, and the total glyphosate removed was only $35 \%$. Therefore, strain BZ8 could be applied for comparatively high salinity glyphosate wastewater treatment.

\section{Growth kinetics of $A$. tumefaciens BZ8}

The consumption of glyphosate and growth of A.tumefaciens BZ8 at various initial glyphosate concentrations were investigated with the same $\mathrm{NaCl}$ concentration of $60 \mathrm{~g} / \mathrm{L}$ (Fig. 6). As shown in Fig. 6, 


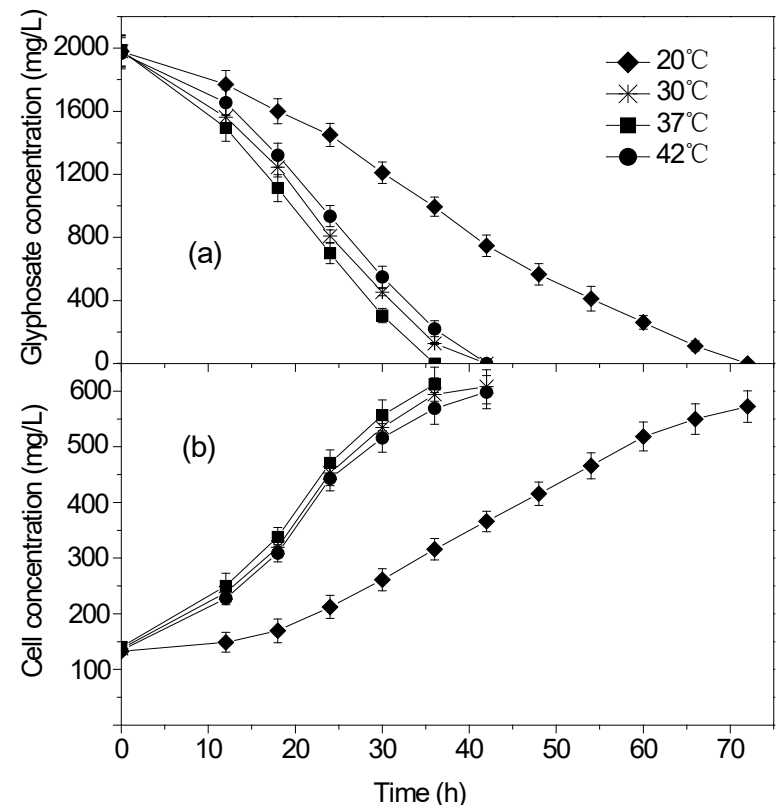

Figure 4. Effect of temperature on biodegradation of glyphosate (a) and cell growth (b) by strain BZ8

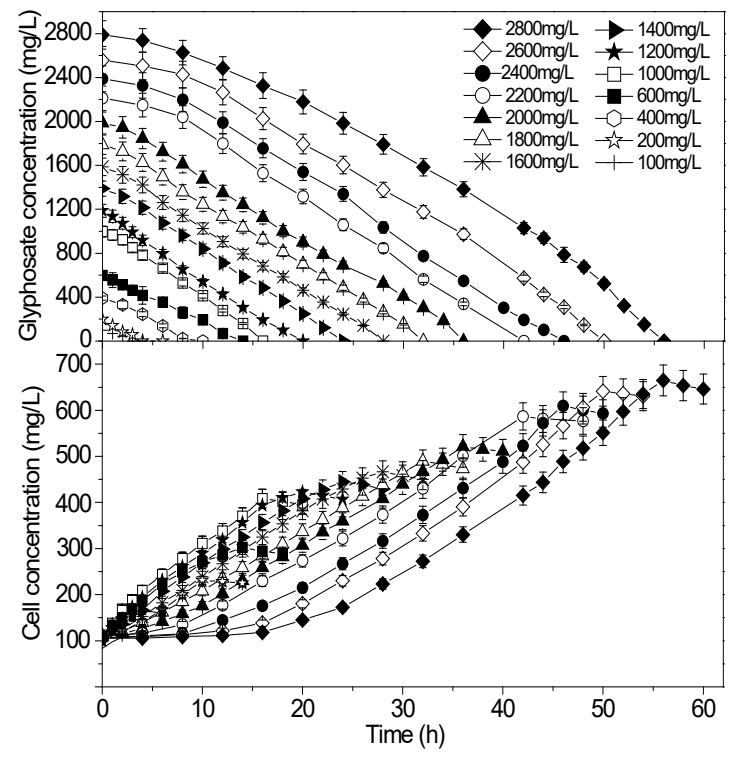

Figure 6. Biodegradation of glyphosate (a) and growth of strain BZ8 (b) at different glyphosate concentration

with the increase of glyphosate concentration, the time to degrade glyphosate thoroughly gradually shortened. It was obvious that the strain BZ8 could completely degrade $2800 \mathrm{mg} / \mathrm{L}$ glyphosate within $56 \mathrm{~h}$ (Fig. 6a). This maximum biodegradable glyphosate concentration of BZ8 was higher than Bacillus cereus CB4 (Fan et al. 2012) and Arthrobacter sp. N4 (Bazot and Lebeau, 2008), and it is inferred that strain BZ8 could tolerate a relatively

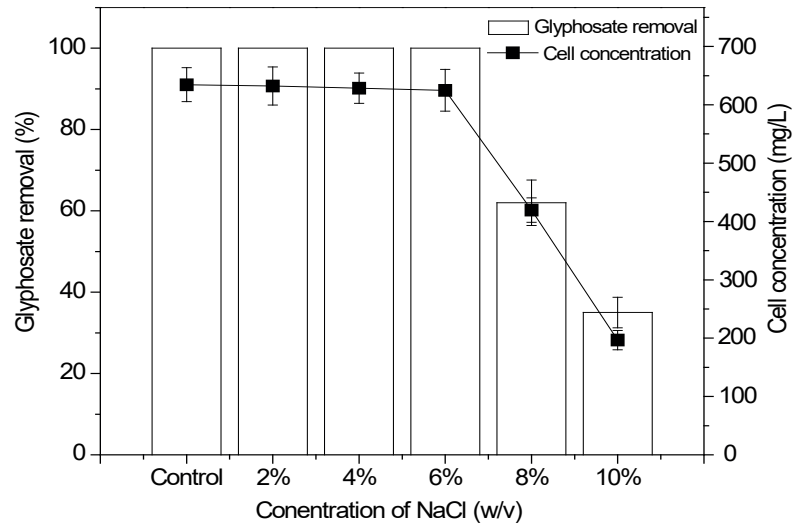

Figure 5. Effect of $\mathrm{NaCl}$ on biodegradation of glyphosate (a) and cell growth (b) by strain BZ8

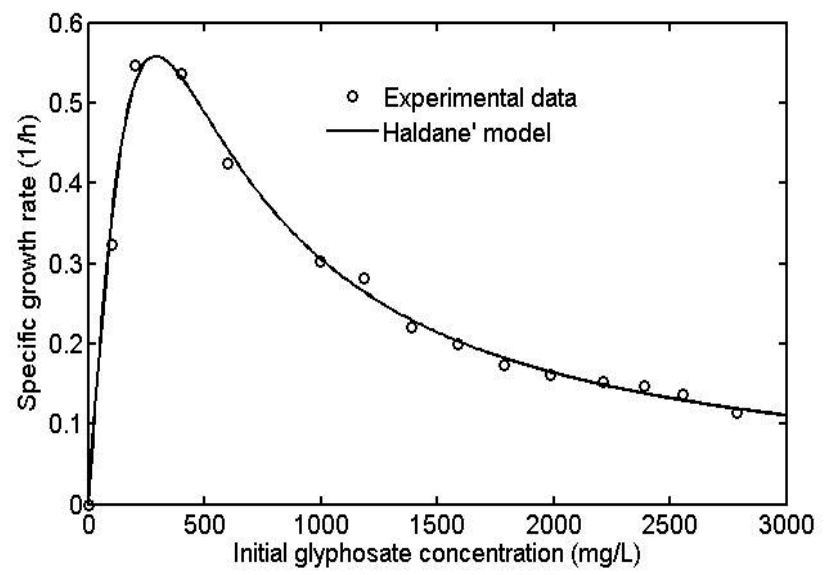

Figure 7. Experimental and predicted specific growth rates of the culture due to Haldane's model

higher concentration of glyphosate than most glyphosatedegrading microorganisms in previous reports.

The biomass and glyphosate concentrations were linearly related for most of the active growth phase, so the yield coefficient $(\mathrm{Ym}, \mathrm{mg} / \mathrm{mg})$ was calculated by linearizing the decline of glyphosate with the increment of cell mass using Equation (3).

All coefficients of correlation (R2) were found to be above 0.99 . The growth yields observed in this study varied between $0.201 \mathrm{mg} / \mathrm{mg}$ and $0.353 \mathrm{mg} / \mathrm{mg}$ as the initial glyphosate concentration was varied from 100 to $2800 \mathrm{mg} / \mathrm{L}$ (Fig. 6b). The highest value $(0.353 \mathrm{mg} / \mathrm{mg}$ ) was found at a glyphosate concentration of $200 \mathrm{mg} / \mathrm{L}$, where the maximum specific growth rate was also obtained (Fig. 7).

When the concentrations were between 0 and 200 $\mathrm{mg} / \mathrm{L}$, the values of specific growth rate increased gradually with increase of glyphosate. There was a slight decrease in specific growth rate as the glyphosate concentrations increased from $200 \mathrm{mg} / \mathrm{L}$ to $400 \mathrm{mg} / \mathrm{L}$; however, beyond $400 \mathrm{mg} / \mathrm{L}$, with an increase of glyphosate concentration, a remarkable decline in specific growth rate occurred (Fig. 7). 
The phenomenon could be explained by the fact that the sole carbon source of glyphosate was consumed mainly for assimilation into biomass and energy for cell growth and maintenance. When the inhibition effect of glyphosate becomes predominant above the glyphosate concentration of $400 \mathrm{mg} / \mathrm{L}$, the proportion of the total glyphosate converted to energy for cell growth and maintenance increased as the specific growth rate decreased. More energy is required to overcome the effect of substrate inhibition at high glyphosate concentrations, while the proportion of the total substrate assimilated into biomass decreases as specific growth rates decrease. Therefore, substrate inhibition is known to reduce both specific growth rate and the yield coefficient.

The specific growth rate $(\mu \mathrm{x})$ was estimated using Equation (1) by performing a linear least squares regression on the semi-logarithmic plot of the biomass concentration over cultivation time in the exponential growth phase. Then, the $\mu \mathrm{x}$ data were employed to determine Haldane's parameters by nonlinear least-squares regression analysis using Matlab 7.0. The Haldane parameters for strain BZ8 grown on glyphosate were obtained as $\mu \max =1.281 / \mathrm{h}$, $\mathrm{KS}=84.82 \mathrm{mg} / \mathrm{L}$, and $\mathrm{Ki}=227.59 \mathrm{mg} / \mathrm{L}$ ( $\mathrm{R} 2=0.992)$. It is clear that Haldane's equation was strongly correlated with the experimental data (Fig. 7). This indicates that Haldane equation was suitable to describe the process of strain BZ8 glyphosate degradation in terms of cell growth behavior.

\section{CONCLUSIONS}

In present study, a high salt-tolerant and glyphosatedegrading strain BZ8 was isolated and identified as $A$. tumefaciens. The growth and glyphosate-degrading capability of the stain BZ8 were investigated and the optimum degradation conditions were obtained. Salt tolerance tests showed that the strain grew well and could thoroughly degrade $2000 \mathrm{mg} / \mathrm{L}$ glyphosate in $36 \mathrm{~h}$ when the concentration of $\mathrm{NaCl}$ was lower than $6 \%$, and the glyphosate degradation rate could still reach $62 \%$ when the salt concentration was $8 \%$. The kinetic parameters for strain BZ8 grown on glyphosate according to Haldane's model were $\mu \max =1.281 / \mathrm{h}, \mathrm{KS}=84.82 \mathrm{mg} / \mathrm{L}$, and $\mathrm{Ki}$ $=227.59 \mathrm{mg} / \mathrm{L}$. The results demonstrate that strain BZ8 has a remarkable potential for application in the disposal of industrial glyphosate wastewater.

\section{ACKNOWLEDGEMENT}

The present research was financially supported by Anhui Provincial Natural Science Foundation (Grant No. 1508085QC56), the Key research and development project of Anhui Province (Public welfare research linkage1704f0704067), the National Natural Science Funds Fund (grant no. 31501461), the foundation of Huainan science and technology planning project (grant no. 1095), the Liquor Making Biological Technology and Application of key laboratory of Sichuan Province (grant no. NJ201418), the Key project of Natural Science Foundation of Anhui Provincial Department of Education (Grant No. KJ2015A279), the Key projects of domestic and foreign research and training of outstanding young and middle aged backbone talents in Universities (gxfxZD2016203).

\section{REFERENCES}

Amoros, I., Alonso, J.L., Romaguera, S., Carrasco, J.M., Assessment of toxicity of a glyphosate-based formulation using bacterial systems in lake water. Chemosphere, 67, 2221-2228 (2007).

Bazot, S., Lebeau, T., Simultaneous mineralization of glyphosate and diuron by a consortium of three bacteria as free-and/or immobilized-cells formulations. Applied Microbiology and Biotechnology, 77, 1351-1358 (2008).

Dong, X.Z., Caim, M.Y., Determinative manual for routine bacteriology. Scientific Press, Beijing (English translation) (2001).

Fan, J.Y., Yang, G.X., Zhao, H.Y., Shi, G.Y., Geng, Y.C., Hou, T.P., Tao, K., Isolation, identification and characterization of a glyphosate-degrading bacterium from soil. Bacillus cereus CB4. Journal of General and Applied Microbiology, 58, 263271 (2012).

Kawai, S., Uno, B., Tomita, M., Determination of glyphosate and its metabolite aminomethylphophonic acid by highperformance liquid chromatograhy after derivatization with para-toluenesulfonyl chloride. Journal of Chromatography, 540, 411-415 (1991).

Liu, B., Liu, G. H., Hu, G. P., Sengonca, C., Lin, N. Q., Tang, J. Y., Tang, W. Q., Lin, Y. Z., Bacillus bingmayongensissp. nov., isolated from the pit soil of Emperor Qin's Terra-cotta warriors in China. Antonie van Leeuwenhoek, 105: 501-510 (2014).

Li, Y., Li, J., Wang, C., Wang, P., Growth kinetics and phenol biodegradation of psychrotrophic Pseudomonas putida LY1. Bioresource Technology, 101, 6740-6744 (2010).

Pipke, R., Amrhein, N., Isolation and characterization of a mutant of Arthrobacter sp. strain GLP-1 which utilizes the herbicide glyphosate as its sole source of phosphorus and nitrogen. Applied and Environmental Microbiology, 54, 2868-2870 (1988).

Simbert, R.M., Krieg, N.R., Phenotypic characterization. In: Gerhare P, Murray RGE, Wood WA, Krieg NR (eds), Methods for general and molecular bacteriology. American Society for Microbiology, Washington, DC, p. 647-654 (1994).

Tamura, K., Dudley, J., Nei, M., MEGA 4: Molecular evolutionary genetics analysis (MEGA) software version 4.0. Molecular Biology and Evolution, 24, 1596-1599 (2007).

Tang, M.Q., Chen, J.X., Isolation, Identification and Biological Properties of a Glyphosate-degrading Strain C-17 (In Chinese). Journal of Fuqing Branch Fujian Normal University, 98, 1-5 (2010). 
Terry M., Balthazor E., Hallas E., Glyphosate-degrading microorganisms from industrial activated sludge. Applied and Environmental Microbiology, 51(2), 432-434 (1986).

Vasiliadou, I., Tziotzios, G., Vayenas, D., A kinetic study of combined aerobic biological phenol and nitrate removal in batch suspended growth cultures. International Biodeterioration \& Biodegredation, 61, 261-271(2008).

Wu, X.H., Fu, G.M., Wan, Y., Guo, D.B., Cheng, Y.H., Luo, Y.F., Wu, X.F., Isolation and Identification of Glyphosatedegrading strain Aspergillus oryzae sp. A-F02 and Its degradation characteristics (In Chinese). Journal of Anhui Agricultural Science, (15), 7731-7733 (2010).

Xu, M.L., Cui, S.H., Wang, Y.P., Peng, P.Y., Pretreatment and recovery utilization of glyphosate wastewater (in Chinese). Journal of Nanjing Normal University Engineering Technology Edition, 7, 51-53 (2007).

Zhai, Z.J., Wang, H.L., Yan, S.B., Yao, J.M., Biodegradation of phenol at high concentration by a novel bacterium: Gulosibacter sp. YZ4. Journal of Chemical Technology and Biotechnology, 87, 105-111 (2012). 